\title{
Analisis Karakteristik Beton dengan Kombinasi Bahan Tambah Plastiment-VZ dan Sikament-NN Pada Pekerjaan Rigid Pavement di Provinsi Riau
}

\author{
SHANTI WAHYUNI MEGASARI ${ }^{1 *}$ dan WINAYATI ${ }^{2}$ \\ 1,2 Program Studi Teknik Sipil, Fakultas Teknik, \\ Universitas Lancang Kuning \\ Jalan Yos Sudarso Km. 8, Pekanbaru, Indonesia \\ Corresponding author: shanti@unilak.ac.id
}

\begin{abstract}
Abstrak: Provinsi Riau memiliki lahan gambut seluas 3.867 .000 ha, yang setara dengan $44,44 \%$ dari total luas wilayah Provinsi Riau. Karakteristik gambut dengan daya dukung yang rendah, sifat permeabilitas yang tinggi dan sifat pemampatan (konsolidasi) yang sangat tinggi mengakibatkan kondisi jalan dengan flexible pavement sering mengalami kerusakan. Sehingga saat ini di Provinsi Riau rigid pavement menjadi alternatif dalam pengembangan konstruksi jalan. Disisi lain pelaksanaan pencampuran dan pengadukan beton pada pekerjaan rigid pavement dengan ready mix sering mengalami kendala yaitu jika diperjalanan diperlukan agar kondisi beton selalu encer atau kelecakan (workabilty) tinggi, namun setelah beton dituang diperlukan kondisi beton dapat segera mengeras untuk mempercepat proses pekerjaan di lapangan. Hal yang berlawanan tersebut mengakibatkan kesulitan dalam pelaksanaan pekerjaan. Plastiment-VZ merupakan bahan plasticizer yang mampu meningkatkan kelecakan beton tanpa menambah air sedangkan Sikament-NN merupakan superplasticizer yang sangat efektif dalam mengurangi jumlah air beton serta untuk membantu menghasilkan kekuatan awal dan kekuatan akhir tinggi. Apabila kedua bahan tersebut dikombinasikan maka dapat menjaga kelecakan (workabilty), percepatan pengerasan beton dan kualitas dari kekuatan beton. Perancangan campuran beton menggunakan metode Departement of Environment (DOE) dengan kuat tekan rencana pada pekerjaan rigid pavement yaitu K-300. Persentase penambahan Plastiment-VZ yaitu 0\%, 0,05\%, 0,10\%, 0,15\% dan $0,20 \%$ serta persentase Sikament-NN sebesar $0 \%$ dan 1,3\% terhadap berat semen. Benda uji yang digunakan berbentuk silinder dengan diameter $15 \mathrm{~cm}$ dan tinggi $30 \mathrm{~cm}$. Pengujian kuat tekan beton dilaksanakan pada umur 28 hari. Hasil pengujian menunjukkan bahwa kecenderungan (trend) grafik kuat tekan rata-rata mengalami peningkatan seiring dengan penambahan persentase Plastiment-VZ. Nilai kuat tekan rata-rata dengan kombinasi penambahan Plastiment-VZ dan Sikament-NN lebih tinggi dibandingkan dengan penambahan Plastiment-VZ saja. Nilai kuat tekan tertinggi diperoleh pada penambahan $0,15 \%$ Plastiment-VZ dan $1,3 \%$ Sikament-NN yaitu sebesar $565,22 \mathrm{~kg} / \mathrm{cm}^{2}$. Sehingga dapat disimpulkan bahwa kombinasi penambahan Plastiment-VZ dan Sikament-NN dapat meningkatkan karakteristik beton pada pekerjaan rigid pavement.
\end{abstract}

Kata kunci: Beton, Kuat Tekan, Plastiment-VZ, Rigid Pavement, Sikament-NN

\section{PENDAHULUAN}

Lahan gambut merupakan suatu ekosistem lahan basah yang dibentuk dari penimbunan bahan organik di lahan hutan yang berasal dari reruntuhan vegetasi dalam kurun waktu yang lama. Karakteristik gambut dengan daya dukung yang rendah, sifat permeabilitas yang tinggi dan sifat pemampatan (konsolidasi) yang sangat tinggi mengakibatkan kondisi jalan dengan perkerasan lentur (flexible pavement) sering mengalami kerusakan. Sehingga saat ini di Provinsi Riau dengan perkerasan kaku (rigid pavement) menjadi alternatif dalam pengembangan konstruksi jalan.

Rigid pavement mempunyai sifat yang lebih kaku serta dapat menyebarkan beban pada bidang yang luas dan menghasilkan tegangan yang rendah pada lapisan-lapisan di bawahnya. Rigid pavement memiliki nilai modulus elastisitas yang lebih besar dibandingkan dengan perkerasan lentur. Pada rigid pavement penyebaran gaya 
sepenuhnya dipikul oleh pelat beton sehingga lebih sesuai untuk digunakan pada kondisi lahan gambut.

Untuk pembangunan konstruksi pada pekerjaan rigid pavement di Provinsi Riau sudah beralih dengan menggunakan beton ready mix. Beton ready mix merupakan solusi dalam pengadukan beton dengan kapasitas besar. Namun penggunaan beton ready mix di lapangan sering mengalami beberapa kendala, antara lain jarak tempuh yang cukup jauh antara batching plant dengan lokasi proyek, kondisi jalan yang rusak dan kemacetan yang tidak bisa diprediksi, waktu tunggu antara pembongkaran mobil ready mix satu dengan berikutnya dan faktor-faktor lainnya. Apabila kondisi tersebut tidak diatasi maka akan mempengaruhi kualitas, kelecakan (workabilty) beton serta kondisi beton yang tidak maksimal.

Namun disisi lain, setelah mobil ready mix sampai di lokasi proyek dan beton selesai dituang pada cetakan, maka pada beberapa pekerjaan dibutuhkan kebalikan dari kondisi sebelumnya. Jika diperjalanan diperlukan agar kondisi beton selalu encer atau kelecakan (workabilty) tinggi, maka setelah beton dituang akan diperlukan beton untuk dapat segera mengeras sehingga dapat mempercepat proses pekerjaan di lapangan. Hal yang berlawanan tersebut tentu saja mengakibatkan kesulitan dalam pelaksanaan pekerjaan dan diperlukan perlakuan khusus dalam penanganannya.

Untuk mengatasi masalah tersebut, kemajuan teknologi beton telah menghasilkan bahan tambah (additive) yang dapat membantu dalam menjaga kualitas dan kelecakan (workabilty) beton serta mempercepat pengerasan.
Salah satu produk keluaran dari PT. Sika Indonesia adalah Plastiment-VZ dan Sikament-NN. Plastiment-VZ merupakan bahan plasticizer yang mampu meningkatkan kelecakan beton tanpa menambah air sedangkan Sikament-NN merupakan superplasticizer yang sangat efektif dalam mengurangi jumlah air beton untuk membantu menghasilkan kekuatan awal dan kekuatan akhir tinggi [4]. Kedua bahan tersebut memiliki kelebihan masing-masing, sehingga jika dimanfaatkan secara bersama-sama akan dapat menghasilkan produk beton yang sesuai dan dapat diaplikasikan di lapangan.

Akan tetapi untuk penggunaan di lapangan, pemilihan bahan tambah harus disesuaikan dengan situasi dan kondisi beton yang telah direncanakan. Pemakaian bahan tambah yang berlebihan juga akan mengakibatkan beton tidak ekonomis, mengingat harga dari suatu bahan tambah sangat mahal.

Dengan kondisi di lapangan tersebut, maka diperlukannya penelitian untuk menganalisis karakteristik kuat tekan beton dengan variasi kombinasi persentase bahan tambah Sikament-NN dan Plastiment-VZ.

\section{LANDASAN TEORI}

\section{A. Perkerasan Kaku (Rigid Pavement)}

Perkerasan kaku (rigid pavement) merupakan konstruksi yag terdiri dari pelat beton semen yang bersambung tanpa atau dengan tulangan, tanpa atau dengan pengaspalan sebagai lapis aus [6]. Perbedaan antara perkerasan lentur dengan perkerasan kaku sesuai dengan tabel 1 . 
Tabel 1 : Perbedaan antara perkerasan lentur dengan perkerasan kaku

\begin{tabular}{|c|c|c|}
\hline No & Keterangan & Perkerasan Lentur \\
\hline 1 & $\begin{array}{l}\text { Umur rencana (masa } \\
\text { pelayanan) }\end{array}$ & $\begin{array}{ll}\text { Umur rencana efektif } 5 \text { sampai } 10 & \text { Umur rencana dapat mencapai } \\
\text { tahun. Perlu beberapa tahap } & 20 \text { sampai } 30 \text { tahun dalam satu } \\
\text { pembangunan masa pelayanan } & \text { kali konstruksi }\end{array}$ \\
\hline 2 & Lendutan & Cenderung untuk melendut \\
\hline 3 & $\begin{array}{l}\text { Perilaku terhadap beban } \\
\text { berlebih }\end{array}$ & $\begin{array}{l}\text { Perkerasan lentur lebih sensitif pada overloading dibandingkan } \\
\text { perkerasan kaku. Sensitifitas ini dikaitkan dengan perilaku lendutan }\end{array}$ \\
\hline 4 & Tingkat kebisingan & $\begin{array}{l}\text { Perkerasan lentur memiliki tingkat kebisingan yang lebih rendah } \\
\text { dibandingkan perkerasan kaku }\end{array}$ \\
\hline 5 & Pantulan cahaya & $\begin{array}{l}\text { Perkerasan lentur mempunyai daya pantul terhadap cahaya lebih } \\
\text { lemah dibandingkan perkerasan kaku }\end{array}$ \\
\hline 6 & Bentuk permukaan & $\begin{array}{l}\text { Permukaan perkerasan lentur lebih halus sehingga terasa lebih } \\
\text { nyaman untuk kendaraan dibandingkan perkerasan kaku }\end{array}$ \\
\hline 7 & Proses konstruksi & $\begin{array}{lllr}\text { Relatif lebih mudah dan cepat. } & \text { Dengan teknologi bahan aditif } \\
\text { Dengan teknologi campuran, } & \text { untuk beton maka proses } \\
\text { waktu yang diperlukan dari mulai } & \text { pematangan beton dapat } \\
\text { penghamparan sampai dibuka } & \text { dipercepat antara satu sampai } \\
\text { untuk lalu lintas hanya } & \text { dua hari, tetapi beton yang } \\
\text { membutuhkan waktu sekitar } 2 & \text { terlalu cepat matang cenderung } \\
\text { jam saja } & & \text { untuk menjadi retak }\end{array}$ \\
\hline 8 & Perawatan & $\begin{array}{l}\begin{array}{l}\text { Memerlukan perawatan rutin } \\
\text { tetapi relatif lebih mudah }\end{array} \\
\begin{array}{l}\text { Tidak perlu perawatan rutin, } \\
\text { tetapi perbaikan kerusakan } \\
\text { relatif lebih sulit }\end{array}\end{array}$ \\
\hline 9 & $\begin{array}{l}\text { Biaya konstruksi dan } \\
\text { perawatan }\end{array}$ & $\begin{array}{ll}\text { Dikaitkan dengan proses } & \text { Biaya awal relatif lebih mahal } \\
\text { konstruksi maka biaya awal lebih } & \text { tetapi relatif tidak memerlukan } \\
\text { murah tetapi perlu ada perawatan } & \text { perawatan rutin, untuk masa } \\
\text { rutin tahunan atau lima } & \text { umur yang sama }\end{array}$ \\
\hline 10 & $\begin{array}{l}\text { Karakteristik terhadap } \\
\text { pembebanan }\end{array}$ & 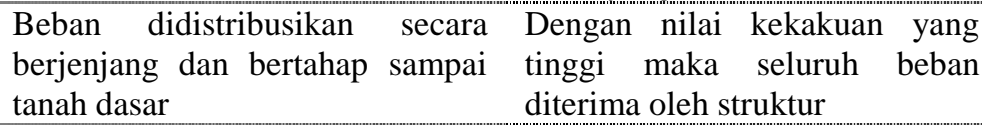 \\
\hline 11 & Karakteristik material & $\begin{array}{lll}\text { Material utama adalah agregat, } & \text { Material utama adalah agregat, } \\
\text { aspal dan filler (jika diperlukan). } & \text { semen dan filler (jika } \\
\text { Sangat sensitif terhadap air } & \text { diperlukan). Air dapat } \\
& \text { membantu proses pematangan } \\
& \text { beton } & \\
\end{array}$ \\
\hline
\end{tabular}

(Sumber : Sukirman S, 1999)

\section{B. Sikament-NN}

Sikament-NN merupakan superplasticizer dengan pengurang air dalam jumlah besar dan mempercepat pengerasan beton serta membantu menghasilkan kekuatan awal dan kekuatan akhir tinggi sesuai dengan ASTM C 494-92 type F [4].

Sikament-NN memberikan keuntungan sebagai berikut :

1). Sebagai superplasticizer
a). Kelecakan
(workability)
meningkat tajam, memudahkan
pengecoran untuk struktur

ramping dengan penulangan yang rapat

b). Mengurangi jumlah getaran yang dibutuhkan, waktu pengerasan normal tanpa perlambatan (retardation)

c). Mengurangi resiko pemisahan (segregation) secara signifikan

2). Sebagai bahan pengurang air

a). Pengurangan air hingga $20 \%$ akan memberikan peningkatan $40 \%$ kuat tekan dalam 28 hari

b). Kekuatan tinggi selama 12 jam 
Sikament-NN dapat digunakan dengan dosis $0,30 \%-2,30 \%$ dari berat semen tergantung pada kelecakan dan kuat tekan beton yang diperlukan. SikamentNN dapat ditambahkan ke air adukan sebelum air tersebut dicampurkan dengan agregat atau dalam sebagian kasus ditambahkan langsung ke dalam beton yang baru di aduk. Ketika ditambahkan ke beton yang baru saja diaduk, efek plastizing-nya lebih terlihat. Untuk beton ready mix, Sikament-NN ditambahkan ke beton segera sebelum dituang (discharge) dan setelah pengadukan lebih lanjut selama tiga sampai lima menit. Karakteristik dari Sikament-NN dapat dilihat pada tabel 2.

Tabel 2: Karakteristik Sikament-NN

\begin{tabular}{ll}
\hline Bentuk & $\begin{array}{l}\text { Data Teknis } \\
\text { Formaldehysi Saphtalene }\end{array}$ \\
\hline Warna & Coklat Tua \\
\hline Berat Jenis & $\pm 1,18-1,20 \mathrm{~kg} / \mathrm{ltr}$ \\
\hline Umur dan & $\begin{array}{l}\text { Minimal 1 tahun apabila } \\
\text { disimpan dalam kemasan }\end{array}$ \\
& $\begin{array}{l}\text { asli yang belum dibuka } \\
\text { pada tempat yang kering, }\end{array}$ \\
& sejuk dan teduh \\
\hline Kemasan & $\begin{array}{l}\text { Drum 240 kg, Bulk 1000 } \\
\mathrm{kg}\end{array}$ \\
\hline (Sumber : PT Sika Indonesia, 2011)
\end{tabular}

\section{Plastiment-VZ}

Plastiment-VZ merupakan bahan plasticizer beton dan bahan pengurang air dalam jumlah besar sesuai dengan ASTM dengan efek mempercepat pengerasan, sesuai dengan ASTM C 494-92 tipe D [4].

Plastiment-VZ digunakan sebagai aditif untuk berbagai keperluan beton dimana kondisi pengecorannya memerlukan beton berkualitas tinggi. Keuntungan Plastiment-VZ akan dapat menghasilkan sifat-sifat berikut :

1). Mempercepat waktu pengerasan dalam cuaca panas
2). Mempercepat pengerasan setelah setting

3). Meningkatkan kelecakan tanpa menambah air

4). Mengurangi air tanpa hilangnya kelecakan

5). Meningkatkan mutu beton

6). Mengurangi penyusutan

7). Kontrol slump loss bertahan lama

8). Hasil akhir permukaan yang lebih bagus

9). Bebas klorida, sehingga tidak merusak perkuatan tulangan

Dosis pemakaian Plastiment-VZ adalah $0,15-0,40$ terhadap berat semen. Dosis efektif Plastiment-VZ tergantung pada tipe semen dan mutu agregat dengan dosis umum antara $0,15 \%-0,25 \%$ untuk beton yang mempunyai daya serap rendah terhadap agregat halus. Dosis ini dapat ditingkatkan sampai dengan $0,60 \%$ untuk mengatasi kesulitan dalam hal kualitas semen maupun agregat, temperatur yang tinggi dan sulitnya kondisi pengecoran. Plastiment-VZ harus dicampur terlebih dahulu secara langsung ke dalam campuran air setelah itu baru agregatnya. Karakteristik dari Plastiment-VZ dapat dilihat pada tabel 3.

Tabel 3 : Karakteristik Plastiment-VZ

\begin{tabular}{ll}
\hline & Data Teknis \\
\hline Bentuk & Polyhydroxy Carbon Salts \\
\hline Warna & Kuning \\
\hline Berat Jenis & $1,17-1,19 \mathrm{~kg} / \mathrm{ltr}$ \\
\hline Umur dan & $\begin{array}{l}\text { Minimal 1 tahun apabila } \\
\text { disimpan dalam kemasan }\end{array}$ \\
Penyimpanan & $\begin{array}{l}\text { asli yang belum dibuka } \\
\text { pada tempat yang kering, }\end{array}$ \\
& sejuk dan teduh \\
\hline Kemasan & Drum 240 kg, Bulk 1000 \\
& kg \\
\hline Sumber $:$ PT Sika Indonesia 2011)
\end{tabular}

(Sumber : PT. Sika Indonesia, 2011) 


\section{METODE PENELITIAN}

\section{A. Material Penelitian}

Material yang digunakan adalah :

1). Semen yang digunakan adalah semen Tipe I (Ordinary Portland Cement - OPC), produksi PT. Semen Padang

2). Agregat kasar (batu pecah) yang digunakan berasal dari daerah Pangkalan

3). Agregat halus (pasir) yang digunakan berasal dari daerah Teratak Buluh

4). Air yang digunakan berasal dari air bersih pada Laboratorium Batching Plant PT. Mekar Abadi Mandiri

5). Bahan Tambah yang digunakan adalah Sikament-NN dan Plastiment-VZ produksi PT. Sika Indonesia.

\section{B. Rancangan Benda Uji}

Perancangan beton menggunakan metode Department of Environment (DOE), dengan cetakan silinder dengan ukuran $150 \mathrm{~mm}$ x $300 \mathrm{~mm}$.

Variasi persentase Sikament-NN sesuai dengan hasil maksimum pada penelitian Ramadhani, KC, Yanti, G dan Winayati [5]. Sedangkan penambahan PlastimentVZ disesuaikan dengan dosis yang dianjurkan oleh PT. Sika Indonesia [4]. Kuat tekan rencana yang digunakan sesuai dengan kuat tekan yang biasa digunakan pada pekerjaan rigid pavement yaitu sebesar K-300.

Penelitian dimulai dengan pengujian pendahuluan pada material, pembuatan benda uji, pengecekan nilai slump, tahapan perawatan (perendaman) selama 28 (dua puluh delapan) hari dan dilaksanakan pengujian tekan.
Adapun rincian benda uji dapat dilihat pada tabel 4 .

Tabel 4 : Rancangan benda uji

\begin{tabular}{|c|c|c|c|}
\hline \multirow{2}{*}{$\begin{array}{c}\% \\
\text { Plastiment-VZ }\end{array}$} & \multicolumn{2}{|c|}{$\%$ Sikament-NN } & \multirow{2}{*}{ Jumlah } \\
\hline & 0 & 1,3 & \\
\hline 0 & 3 & 3 & 6 \\
\hline 0,05 & 3 & 3 & 6 \\
\hline 0,10 & 3 & 3 & 6 \\
\hline 0,15 & 3 & 3 & 6 \\
\hline \multirow[t]{2}{*}{0,20} & 3 & 3 & 6 \\
\hline & & Total & 30 \\
\hline
\end{tabular}

\section{Analisis Data Kuat Tekan Beton}

Perhitungan nilai kuat tekan dapat digunakan rumus :

$$
\mathrm{f}^{\prime}{ }_{\mathrm{c}}=\frac{\mathrm{P}_{\max }}{\mathrm{A}_{\mathrm{C}}}
$$

Keterangan :

$$
\begin{array}{ll}
\mathrm{f}_{\mathrm{c}}^{\prime} & =\text { Kuat tekan beton }(\mathrm{MPa}) \\
\mathrm{P}_{\max } & =\text { Beban maksimum }(\mathrm{N}) \\
\mathrm{A}_{\mathrm{c}} & =\text { Luas permukaan }\left(\mathrm{mm}^{2}\right)
\end{array}
$$

\section{HASIL DAN PEMBAHASAN}

\section{A. Hasil Pengujian Kuat Tekan Beton}

Hasil pengujian menunjukkan bahwa kuat tekan beton seluruh benda uji dengan penambahan Plastiment-VZ dan Sikament-NN lebih besar dibandingkan dengan kuat tekan rencana yaitu K-300. Hasil pengujian terhadap benda uji menunjukkan terjadi peningkatan nilai kuat tekan beton pada kombinasi penambahan Plastiment-VZ dan Sikament-NN dibandingkan dengan hanya menggunakan Plastiment-VZ.

Hasil pengujian kuat tekan benda uji dengan penambahan Plastiment-VZ dan Sikament-NN dapat dilihat pada Tabel 5 dan pada gambar 1 serta gambar 2 . 
Tabel 5 : Hasil pengujian kuat tekan beton

\begin{tabular}{|c|c|c|c|c|c|c|c|}
\hline $\begin{array}{c}\% \\
\text { Plastiment-VZ }\end{array}$ & $\begin{array}{c}\% \\
\text { Sikament-NN }\end{array}$ & $\begin{array}{c}\text { Benda } \\
\text { Uji }\end{array}$ & $\begin{array}{l}\text { Berat } \\
(\mathrm{g})\end{array}$ & $\begin{array}{l}\text { Luas } \\
\left(\mathbf{c m}^{2}\right)\end{array}$ & $\begin{array}{c}\text { Beban } \\
(\mathbf{k N})\end{array}$ & $\begin{array}{c}\text { Kuat } \\
\text { Tekan } \\
\left(\mathrm{Kg} / \mathrm{cm}^{2}\right)\end{array}$ & $\begin{array}{c}\text { Kuat } \\
\text { Tekan } \\
\text { Rata-rata } \\
\left(\mathbf{K g} / \mathbf{c m}^{2}\right) \\
\end{array}$ \\
\hline \multirow{6}{*}{0} & \multirow{3}{*}{0} & I & 12680 & 176,79 & 520 & 361,37 & \multirow{3}{*}{331,25} \\
\hline & & II & 12810 & 176,79 & 460 & 319,67 & \\
\hline & & III & 12860 & 176,79 & 450 & 312,72 & \\
\hline & \multirow{3}{*}{1,3} & I & 12510 & 176,79 & 650 & 451,71 & \multirow{3}{*}{423,91} \\
\hline & & II & 12725 & 176,79 & 560 & 389,17 & \\
\hline & & III & 12298 & 176,79 & 620 & 430,86 & \\
\hline \multirow{6}{*}{0,05} & \multirow{3}{*}{0} & $\mathrm{I}$ & 12910 & 176,79 & 590 & 410,01 & \multirow{3}{*}{423,91} \\
\hline & & II & 12980 & 176,79 & 620 & 430,86 & \\
\hline & & III & 12860 & 176,79 & 620 & 430,86 & \\
\hline & \multirow{3}{*}{1,3} & I & 12810 & 176,79 & 760 & 528,15 & \multirow{3}{*}{539,73} \\
\hline & & II & 12843 & 176,79 & 780 & 542,05 & \\
\hline & & III & 12389 & 176,79 & 790 & 549 & \\
\hline \multirow{6}{*}{0,1} & \multirow{3}{*}{0} & $\mathrm{I}$ & 12840 & 176,79 & 660 & 458,66 & \multirow{3}{*}{451,71} \\
\hline & & II & 12890 & 176,79 & 670 & 465,61 & \\
\hline & & III & 12290 & 176,79 & 620 & 430,86 & \\
\hline & \multirow{3}{*}{1,3} & I & 12490 & 176,79 & 820 & 569,85 & \multirow{3}{*}{555,95} \\
\hline & & II & 12511 & 176,79 & 760 & 528,15 & \\
\hline & & III & 12551 & 176,79 & 820 & 569,85 & \\
\hline \multirow{6}{*}{0,15} & \multirow{3}{*}{0} & I & 12950 & 176,79 & 700 & 486,46 & \multirow{3}{*}{470,24} \\
\hline & & II & 12890 & 176,79 & 660 & 458,66 & \\
\hline & & III & 12980 & 176,79 & 670 & 465,61 & \\
\hline & \multirow{3}{*}{1,3} & I & 12619 & 176,79 & 700 & 486,46 & \multirow{3}{*}{565,22} \\
\hline & & II & 12710 & 176,79 & 920 & 639,34 & \\
\hline & & III & 12471 & 176,79 & 820 & 569,85 & \\
\hline \multirow{6}{*}{0,2} & \multirow{3}{*}{0} & $\mathrm{I}$ & 12850 & 176,79 & 720 & 500,36 & \multirow{3}{*}{491,10} \\
\hline & & II & 12665 & 176,79 & 680 & 472,57 & \\
\hline & & III & 12750 & 176,79 & 720 & 500,36 & \\
\hline & \multirow{3}{*}{1,3} & I & 12811 & 176,79 & 780 & 542,05 & \multirow{3}{*}{535,10} \\
\hline & & II & 12849 & 176,79 & 770 & 535,1 & \\
\hline & & III & 12541 & 176,79 & 760 & 528,15 & \\
\hline
\end{tabular}




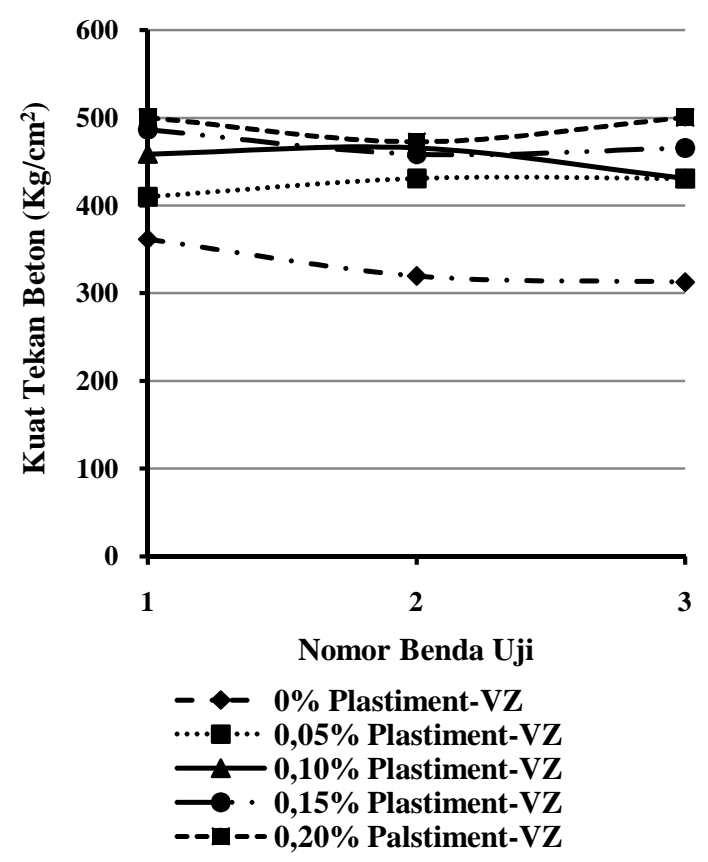

Gambar 1 : Hasil kuat tekan beton pada benda uji dengan penambahan $0 \%$

Sikament-NN dan variasi persentase Plastiment-VZ

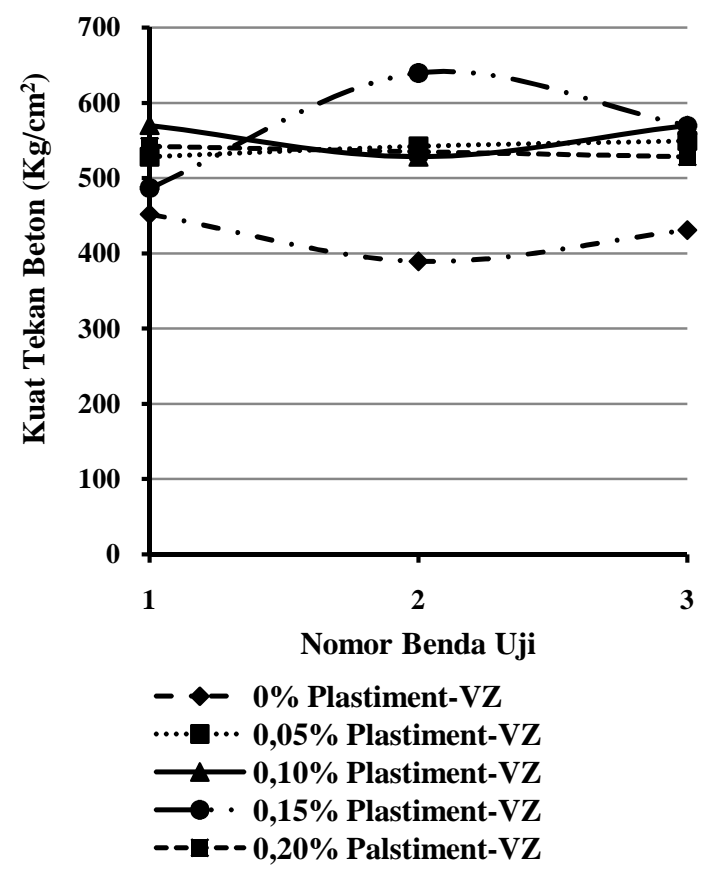

Gambar 2 : Hasil kuat tekan beton pada benda uji dengan penambahan

$1,3 \%$ Sikament-NN dan variasi

persentase Plastiment-VZ
Sedangkan perbandingan nilai kuat tekan beton rata-rata dengan penambahan Plastiment-VZ dan Sikament-NN dapat dilihat di gambar 3.

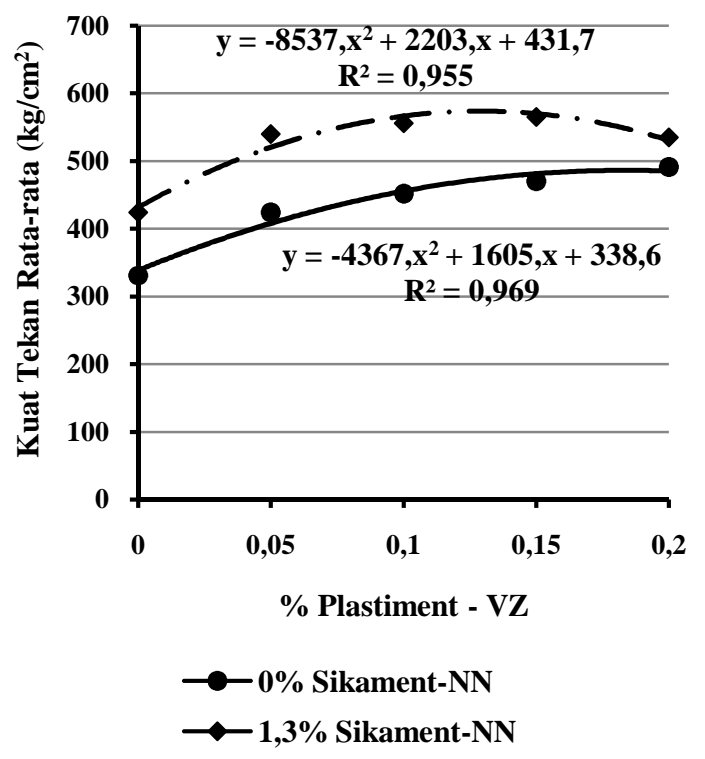

Gambar 3 : Hubungan kuat tekan beton rata-rata dengan penambahan Plastiment-VZ dan Sikament-NN

\section{B. Pembahasan}

Pada penelitian ini digunakan agregat kasar dan agregat halus yang biasa digunakan pada pembuatan rigid pavement di Provinsi Riau. Berdasarkan hasil pengujian pendahuluan material diperoleh bahwa agregat kasar dan agregat halus sesuai dengan persyaratan sebagai bahan campuran beton.

Hasil pengujian menunjukkan bahwa kuat tekan beton seluruh benda uji dengan penambahan Plastiment-VZ dan Sikament-NN lebih besar dibandingkan dengan kuat tekan rencana yaitu K-300. Pemilihan kuat tekan rencana disesuaikan dengan kuat tekan pada pekerjaan rigid pavement yaitu K-300.

Hasil pengujian menunjukkan bahwa kecenderungan (trend) grafik kuat tekan rata-rata mengalami peningkatan seiring 
dengan penambahan persentase Plastiment-VZ.

Nilai kuat tekan rata-rata dengan kombinasi penambahan Plastiment-VZ dan $1,3 \%$ Sikament-NN lebih tinggi dibandingkan dengan penambahan Plastiment-VZ saja. Namun nilai kuat tekan mengalami penurunan pada kombinasi penambahan 0,2\% Plastiment-VZ dan 1,3\% Sikament-NN. Hal tersebut dikarenakan dengan semakin banyaknya persentase Plastiment-VZ dan Sikament-NN maka setelah campuran dikeluarkan dari mesin pengaduk akan segera mengeras, maka campuran harus segera dimasukkan ke dalam cetakan.

Persamaan kuat tekan rata-rata yang diperoleh dengan variasi penambahan Plastiment-VZ sebesar $\mathrm{y}=-4367, \mathrm{x}^{2}+$ $1605, \mathrm{x}+338,6$ dengan $\mathrm{R}^{2}=0,969$. Sedangkan persamaan kuat tekan ratarata yang diperoleh dengan variasi penambahan Plastiment-VZ dan 1,3\% Sikament-NN sebesar $\mathrm{y}=-8537, \mathrm{x}^{2}+$ $2203, x+431,7$ dengan $R^{2}=0,955$

Nilai kuat tekan tertinggi diperoleh pada penambahan $0,15 \%$ Plastiment-VZ dan $1,3 \%$ Sikament-NN yaitu sebesar $565,22 \mathrm{~kg} / \mathrm{cm}^{2}$. Berdasarkan seluruh hasil pengujian dan analisis data diperoleh bahwa kombinasi penambahan Plastiment-VZ dan Sikament-NN dapat meningkatkan karakteristik beton pada pekerjaan rigid pavement.

\section{KESIMPULAN}

Kesimpulan yang diperoleh adalah :

1). Kuat tekan beton seluruh benda uji dengan variasi penambahan Plastiment-VZ dan Sikament-NN lebih besar dibandingkan dengan kuat tekan rencana yaitu K-300
2). Hasil pengujian menunjukkan bahwa kecenderungan (trend) grafik kuat tekan rata-rata mengalami peningkatan seiring dengan penambahan persentase Plastiment-VZ dan Sikament-NN.

3). Nilai kuat tekan rata-rata dengan kombinasi penambahan PlastimentVZ dan 1,3\% Sikament-NN lebih tinggi dibandingkan dengan penambahan Plastiment-VZ saja.

4). Nilai kuat tekan tertinggi diperoleh pada penambahan $0,15 \%$ Plastiment-VZ dan 1,3\% SikamentNN yaitu sebesar 565,22 kg/ $\mathrm{cm}^{2}$.

5). Kombinasi penambahan persentase Plastiment-VZ dan Sikament-NN dapat meningkatkan karakteristik beton pada pekerjaan rigid pavement.

\section{DAFTAR PUSTAKA}

1. Aprilianti, S and Nadia (2012) Analisis Pengaruh Beton dengan Bahan Admixture Naphtalene dan Polycarboxilate Terhadap Kuat Tekan Beton Normal, Jurnal Konstruksia, Vol. 3, No. 2, April 2012:33 - 40.

2. Haerudin, Zainuri and Megasari, SW (2016) Analisis Tambahan Waktu Pengadukan dengan Bahan Tambah Plastiment-VZ Terhadap Nilai Slump, Kuat Tekan dan Kuat Lentur Beton, Pekanbaru, Program Studi Teknik Sipil Universitas Lancang Kuning.

3. Nugraha, $P$ and Antoni (2007) Teknologi Beton, Yogyakarta, Andi Offset.

4. PT. Sika Indonesia (2011) Data Teknis Know-How From Site To Shelf.

5. Ramadhani, KC, Yanti, G and Winayati (2016) Analisis Kuat Tekan Beton Terhadap Variasi Persentase Bahan Tambah Sikament NN, Pekanbaru, Program Studi Teknik Sipil Universitas Lancang Kuning.

6. Sukirman, S (1999) Perkerasan Lentur Jalan Raya, Bandung, Nova. 